\title{
ANALISIS KEPUASAN DAN LOYALITAS KONSUMEN JAMU GENDONG DI KOTA SUKABUMI
}

\author{
Satisfaction and Loyalty Analysis of Traditional Medicinal Herbs Consumer in \\ Sukabumi
}
MUHAMMAD DJEMDJEM DJAMALUDIN ${ }^{1 *}$, UJANG SUMARWAN ${ }^{1}$, GUSTIA NUR ARIA MAHARDIKAWATI ${ }^{2}$

\author{
${ }^{1}$ Staf Pengajar Departemen Ilmu Keluarga dan Konsumen, Fakultas Ekologi \\ Manusia, Institut Pertanian Bogor, Jalan Lingkar Kampus IPB Dramaga, \\ Bogor 16680 \\ ${ }^{2}$ Program Studi Gizi Masyarakat dan Sumberdaya Keluarga, Fakultas Pertanian, \\ Institut Pertanian Bogor, Kampus Dramaga, Bogor 16680
}

\begin{abstract}
The purpose of this study were to analyze satisfaction and loyalty of traditional medicinal herbs consumer in Sukabumi. This study used the concept of traditional approach analysis and brand loyalty. The data were collected from February to March 2008 in Sukabumi. Frequency and descriptive statistics were used to analyze the single variable. Cross tabulations and Chi Square were utilized to examine the relationships between two variables. Factor analysis were used to analyze multivariate. The results of study showed that consumers of traditional medicinal herbs in Sukabumi feel satisfied in many attributes, both product and service. Most consumers had enough loyalty index that is 23,3 . There were significant relationships between characteristics of costumer (marriage status, education, and income) and satisfaction that are consist of six factors (hygiene, characteristic of product, characteristic of traditional medicinal herbs peddler, color of medicinal herbs and medicinal peddler service, friendliness and responsiveness, and marketing mix). Marketing strategy that suggest to increase number of selling traditional medicinal herbs are keeping fresh and hygiene, labeling names of traditional medicinal herbs in every bottles, maintaining price, using word of mouth promotion, using vehicle for distribution (ex: motorcycle or bicycle), and organizing selling location.
\end{abstract}

Key words: loyalty, medicinal herbs, satisfaction

\section{PENDAHULUAN}

Indonesia kaya akan hasil alam dan tanaman obatnya. Menurut data dari Departemen Kehutanan RI, dari seluruh luasan hutan hujan tropis Indonesia diperkirakan terdapat sekitar 30.000 spesies tanaman yang tumbuh di dalamnya. Dari spesies tanaman yang ada tersebut, lebih dari 8.000 spesies merupakan tanaman obat yang mempunyai khasiat obat dan baru 800 1.200 spesies yang telah dimanfaatkan oleh masyarakat untuk obat tradisional dan jamu (Martha Tilaar Innovation Center 2002). Tanaman/tumbuhan obat mempunyai beberapa manfaat terutama bagi manusia yaitu sebagai obat, makanan dan minuman kesehatan, zat pewarna, rempah-rempah, kosmetika, insektisida, pakan/obat ternak, dan lainlain. Untuk mencapai manfaat-manfaat di atas maka diperlukan budidaya tanaman obat dengan cara membuat suatu produk salah satunya jamu.

Menurut World Health Organization (WHO), kira-kira $80 \%$ dari penduduk dunia tahun 2007 yang berjumlah 7,9 miliar, percaya pada manfaat tumbuhtumbuhan untuk kesehatan dan kebugaran tubuh, dan masyarakat modern pun akhirnya lebih menyukai pemakaian bahan-bahan alam segar untuk suplemen, makanan, minuman, sarana kecantikan serta penampilan bagi pria dan wanita (Dwiyono 2007). Melihat 
fakta yang ada tersebut, maka pengembangan pengobatan secara tradisional tentunya semakin dapat merambah permintaan pasar global yang ada saat ini.

Jumlah penjual jamu gendong dari tahun ke tahun semakin tinggi. Data di Departemen Kesehatan RI menunjukkan peningkatan tersebut, yaitu 13.128 pada tahun 1989 , menjadi 25.077 pada tahun 1995. Demikian pula angka untuk Jawa Timur yang menunjukkan jumlah 3.306 pada tahun 1995, yaitu menduduki urutan jumlah terbanyak ketiga setelah Jawa Tengah dan Jawa Barat.

Melihat jumlah yang terus meningkat tersebut, dapat diperkirakan bahwa pemanfaatan jamu gendong masih sangat tinggi. Masyarakat masih berminat untuk mengkonsumsi jamu gendong sebagai salah satu upaya untuk perawatan kesehatan. Keadaan seperti inilah yang membuat pengobatan tradisional peninggalan nenek moyang tersebut dari dahulu hingga saat ini semakin mudah untuk didapatkan oleh para konsumen jamu.

Tujuan umum dari penelitian ini adalah untuk menganalisis tingkat kepuasan dan loyalitas konsumen jamu gendong. Tujuan khususnya adalah: (1) mengidentifikasi karakteristik penjual jamu gendong; (2) mengidentifikasi karakteristik konsumen jamu gendong; (3) mengidentifikasi perilaku konsumsi jamu gendong; (4) menganalisis tingkat kepuasan konsumen jamu gendong; (5) menganalisis loyalitas konsumen jamu gendong; (6) menganalisis hubungan karakteristik konsumen jamu gendong dengan tingkat kepuasan; (7) menganalisis atribut-atribut yang mendasari tingkat kepuasan konsumen jamu gendong; serta (8) merumuskan saran berupa strategi pemasaran berdasarkan hasil penelitian.

\section{METODE}

\section{Desain, Tempat, dan Waktu}

Desain penelitian yang digunakan adalah cross sectional. Penelitian ini dilaksanakan di Kota Sukabumi, Jawa Barat. Pemilihan tempat dilakukan secara sengaja (purposive sampling). Adapun waktu pelaksanaannya mulai dari bulan Februari sampai Maret 2008.

\section{Teknik Penarikan Contoh}

Populasi penelitian ini adalah konsumen dan penjual jamu gendong yang tersebar di Kota Sukabumi. Pengambilan data dilakukan dengan metode snowball sampling. Adapun jumlah responden yang diambil adalah 100 konsumen dan 15 penjual jamu gendong.

\section{Jenis dan Sumber Data}

Data penelitian terbagi atas dua bagian yakni data primer dan data sekunder. Data primer yaitu data yang berasal langsung dari objek penelitian, yaitu berupa hasil dari wawancara kuesioner yang diberikan secara langsung kepada responden untuk memperoleh informasi. Data sekunder yang diperlukan yaitu data keadaan geografi, peta Kota Sukabumi, dan data jumlah penjual jamu pada setiap paguyuban. Sumber data sekunder adalah berasal dari penelusuran pustaka berupa buku penunjang dan searching internet.

\section{Pengolahan dan Analisis Data}

Proses pengolahan dan analisis data menggunakan program Microsoft Excel dan SPSS versi 13.0 for windows. Untuk mengidentifikasi karakteristik konsumen dan penjual jamu gendong digunakan analisis deskriptif. Untuk menganalisis tingkat kepuasan konsumen jamu gendong digunakan teknik Traditional Approach Analysis dimana konsumen diminta memberikan penilaian atas masing-masing atribut jamu gendong dengan menggunakan skala Likert.

Untuk menganalisis atribut-atribut yang mendasari tingkat kepuasan konsumen digunakan analisis faktor (Principal Component Analysis). Variabelvariabel yang akan dianalisis yaitu: $\left(\mathrm{X}_{1}\right)$ khasiat jamu gendong; $\left(X_{2}\right)$ warna jamu gendong; $\left(X_{3}\right)$ aroma jamu gendong; $\left(X_{4}\right)$ rasa jamu gendong; (X5) keragaman/variasi jamu gendong; (X6) kemudahan memperoleh jamu gendong; (X7) harga jamu gendong; (X8) kebersihan gelas; (X9) kebersihan bakul; (X10) kebersihan botol; (X11) kebersihan lap; (X12) kebersihan air; (X13) kandungan bahan-bahan alami; (X14) keterampilan penjual jamu gendong; (X15) kecepatan penjual jamu gendong dalam melayani konsumen; (X16) 
kecepatan penjual jamu gendong dalam menanggapi keluhan konsumen; (X17) kesesuaian pesanan; (X18) keramahan dan kesopanan penjual jamu gendong; (X19) penampilan penjual jamu gendong; (X20) kemampuan berkomunikasi penjual jamu gendong; dan (X21) kebersihan penjual jamu gendong.

Untuk mengkaji hubungan antara karakteristik responden dengan tingkat kepuasan digunakan uji Chi-square. Sedangkan untuk analisis loyalitas digunakan analisis deskriptif menurut Durianto et al. (2004) dengan menggambarkan kategori persentase dari switcher buyer, habitual buyer, likes the brand, satisfied buyer, dan committed buyer.

\section{HASIL DAN PEMBAHASAN}

\section{Karakteristik Penjual Jamu Gendong}

Tabel 1 memperlihatkan bahwa semua penjual jamu gendong berjenis kelamin perempuan, merupakan Suku Jawa dan sudah menikah. Menurut Sutarno (2000) ciri khas penjual jamu biasanya menggunakan kebaya. Pada umumnya penjual jamu gendong adalah kaum wanita. Lebih dari separuh penjual jamu gendong $(66,7 \%)$ berusia 21-40 tahun dan berasal dari daerah Solo $(73,3 \%)$. Sebagian besar tingkat pendidikan terakhir penjual jamu adalah SD $(60 \%)$. Hal ini dikarenakan jamu gendong merupakan usaha dalam sektor informal, dimana biasanya penjual tidak mempunyai pendidikan tinggi, tapi cukup pengetahuan, keuletan dalam berusaha dan keterampilan berdasarkan pengalaman. Hampir separuh penjual jamu gendong $(46,7 \%)$ mempunyai pendapatan keluarga per bulan sebesar Rp 700.001,00 - Rp 1.000.000,00. Pendapatan ini tidak hanya didapat dari berjualan jamu gendong saja, tapi juga dari penghasilan suami/anak dan biasanya beberapa penjual mempunyai usaha sampingan seperti berjualan bubur sumsum atau usaha kredit. Sebesar $46,6 \%$ penjual jamu gendong mempunyai pendapatan per hari $\operatorname{Rp} 40.001,00$ Rp 100.000,00.

Pada umumnya penjual jamu gendong sudah cukup lama tinggal di Kota Sukabumi yaitu $\geq 24-49$ tahun (40\%). Alasan penjual tinggal di Kota Sukabumi karena ajakan suami. Selain cukup lama tinggal di Kota Sukabumi, kebanyakan penjual jamu gendong juga sudah cukup lama berjualan jamu gendong yaitu $\geq 19-40$ tahun dan alasan penjual memutuskan untuk berjualan jamu gendong dikarenakan kebutuhan ekonomi. Sebagian besar penjual berjualan jamu buatan sendiri pada pagi hari dimana sebagian besar bahan baku yang digunakan dibeli di pasar-pasar terdekat. Modal usaha yang dikeluarkan adalah >Rp 50.000,00 - Rp 100.000,00.

Tabel 1. Sebaran karakteristik penjual jamu gendong contoh

\begin{tabular}{|c|c|c|c|}
\hline \multicolumn{2}{|c|}{$\begin{array}{l}\text { Karakteristik Penjual Jamu } \\
\text { Gendong }\end{array}$} & \multirow{2}{*}{$\begin{array}{l}\mathbf{n} \\
15\end{array}$} & \multirow{2}{*}{$\begin{array}{c}\% \\
100\end{array}$} \\
\hline Jenis & Perempuan & & \\
\hline \multirow[t]{2}{*}{ kelamin } & Laki-laki & 0 & 0 \\
\hline & Total & 15 & 100 \\
\hline \multirow[t]{3}{*}{ Usia (tahun) } & $21-40$ & 10 & 66,7 \\
\hline & $41-65$ & 5 & 33,3 \\
\hline & Total & 15 & 100 \\
\hline \multirow[t]{3}{*}{ Suku } & Sunda & 15 & 100 \\
\hline & Luar Sunda & 0 & 0 \\
\hline & Total & 15 & 100 \\
\hline \multirow[t]{3}{*}{ Asal daerah } & Solo & 11 & 73,3 \\
\hline & Sukoharjo & 4 & 26,7 \\
\hline & Total & 15 & 100 \\
\hline \multirow{3}{*}{$\begin{array}{l}\text { Status } \\
\text { pernikahan }\end{array}$} & Belum menikah & 0 & 0 \\
\hline & Menikah & 15 & 100 \\
\hline & Total & 15 & 100 \\
\hline \multirow{5}{*}{$\begin{array}{l}\text { Tingkat } \\
\text { pendidikan }\end{array}$} & SD & 9 & 60,0 \\
\hline & SMP & 3 & 20,0 \\
\hline & SMA & 3 & 20,0 \\
\hline & PT (D3/S1) & 0 & 0 \\
\hline & Total & 15 & 100 \\
\hline \multirow{4}{*}{$\begin{array}{l}\text { Tingkat } \\
\text { pendapatan } \\
\text { (Rp/bulan) }\end{array}$} & $\leq 700.000$ & 5 & 33,3 \\
\hline & $\begin{array}{l}700.001,00- \\
1.000 .000,00\end{array}$ & 7 & 46,7 \\
\hline & $\geq 1.000 .000,00$ & 3 & 20,0 \\
\hline & Total & 15 & 100 \\
\hline \multirow{4}{*}{$\begin{array}{l}\text { Lama } \\
\text { tinggal } \\
\text { (tahun) }\end{array}$} & $\leq 10$ & 4 & 26,7 \\
\hline & $11-24$ & 5 & 33,3 \\
\hline & $\geq 24-49$ & 6 & 40,0 \\
\hline & Total & 15 & 100 \\
\hline \multirow{4}{*}{$\begin{array}{l}\text { Tingkat } \\
\text { pendapatan } \\
\text { (Rp/hari) }\end{array}$} & $\leq 40.000,00$ & 4 & 26,7 \\
\hline & $\begin{array}{l}40.001,00- \\
100.000,00\end{array}$ & 7 & 46,6 \\
\hline & $\geq 100.000,00$ & 4 & 26,7 \\
\hline & Total & 15 & 100 \\
\hline Modal & $\leq 20.000,00$ & 4 & 26,7 \\
\hline \multirow[t]{3}{*}{ usaha } & $20.001,00-50.000,00$ & 4 & 46,6 \\
\hline & $>50.000,00$ & 7 & 26,7 \\
\hline & Total & 15 & 100 \\
\hline
\end{tabular}

\section{Karakteristik Konsumen Jamu Gendong}

Tabel 2 memperlihatkan bahwa sebagian besar (95\%), konsumen jamu gendong yang menjadi responden berjenis kelamin perempuan, sudah menikah $(85 \%)$, dan merupakan Suku Sunda (95\%). Lebih dari separuhnya 
(59\%) berusia 21-40 tahun dengan tingkat pendidikan terakhir SMA (42\%). Sebesar $67 \%$ adalah ibu rumah tangga dengan tingkat pendapatan keluarga per bulan Rp 600.001,00 - Rp 1.500.000,00 (53\%).

Tabel 2. Sebaran karakteristik konsumen jamu gendong contoh

\begin{tabular}{|c|c|c|}
\hline \multicolumn{2}{|c|}{ Karakteristik konsumen } & $\%$ \\
\hline \multirow[t]{3}{*}{ Jenis kelamin } & Perempuan & 95 \\
\hline & Laki-laki & 5 \\
\hline & Total & 100 \\
\hline \multirow[t]{5}{*}{ Usia (tahun) } & $12-20$ & 8 \\
\hline & $21-40$ & 59 \\
\hline & $41-65$ & 32 \\
\hline & $>65$ & 1 \\
\hline & Total & 100 \\
\hline \multirow[t]{3}{*}{ Suku } & Sunda & 95 \\
\hline & Luar Sunda & 5 \\
\hline & Total & 100 \\
\hline \multirow{3}{*}{$\begin{array}{l}\text { Status } \\
\text { pernikahan }\end{array}$} & Belum menikah & 15 \\
\hline & Menikah & 85 \\
\hline & Total & 100 \\
\hline \multirow{5}{*}{$\begin{array}{l}\text { Tingkat } \\
\text { pendidikan }\end{array}$} & SD & 25 \\
\hline & SMP & 19 \\
\hline & SMA & 42 \\
\hline & PT (D3/S1) & 14 \\
\hline & Total & 100 \\
\hline \multirow[t]{6}{*}{ Pekerjaan } & Mahasiswa & 12 \\
\hline & Ibu rumah tangga & 67 \\
\hline & PNS/TNI/POLRI & 6 \\
\hline & Pegawai swasta & 8 \\
\hline & Wiraswasta/buruh & 7 \\
\hline & Total & 100 \\
\hline \multirow{4}{*}{$\begin{array}{l}\text { Tingkat } \\
\text { pendapatan } \\
\text { keluarga } \\
\text { (Rp/bulan) }\end{array}$} & $\leq 600.000$ & 32 \\
\hline & $600.001-1.500 .000$ & 53 \\
\hline & $\geq 1.500 .000-2.000 .000$ & 15 \\
\hline & Total & 100 \\
\hline
\end{tabular}

\section{Perilaku Konsumsi}

Tabel 3 memperlihatkan bahwa lebih dari separuh konsumen (65\%) mengkonsumsi jamu jenis kunyit asam. Sebesar 63\% mengkonsumsi jamu gendong dengan alasan ingin memelihara kesehatan, hal ini sesuai dengan penelitian Pali (1994) bahwa sebagian besar konsumen mengkonsumsi jamu untuk pemeliharaan kesehatan bukan untuk pengobatan. Hampir separuh konsumen $(31 \%)$ mengkonsumsi jamu gendong karena adanya pengaruh dari orang tua dan mayoritas mengkonsumsi jamu gendong pada pagi hari. Hampir separuh konsumen mengkonsumsi jamu gendong 2-4 kali per minggu dengan pengeluaran per minggu yaitu Rp 1.001,00 sampai $\operatorname{Rp} 3.000,00$.
Tabel 3. Sebaran perilaku konsumsi konsumen jamu gendong contoh

\begin{tabular}{|c|c|c|}
\hline \multicolumn{2}{|c|}{ Perilaku konsumsi jamu gendong } & $\mathbf{n}$ \\
\hline \multirow{7}{*}{$\begin{array}{l}\text { Jenis jamu } \\
\text { gendong }\end{array}$} & Beras kencur & 22 \\
\hline & Kunyit asam & 65 \\
\hline & Pahitan/sambiloto & 5 \\
\hline & Anggur & 3 \\
\hline & Kunyit putih & 3 \\
\hline & Sirih & 2 \\
\hline & Total & 100 \\
\hline \multirow{4}{*}{$\begin{array}{l}\text { Alasan } \\
\text { konsumsi }\end{array}$} & Kebiasaan & 6 \\
\hline & $\begin{array}{l}\text { Khasiat dari jamu } \\
\text { gendong }\end{array}$ & 31 \\
\hline & $\begin{array}{l}\text { Memelihara } \\
\text { kesehatan }\end{array}$ & 63 \\
\hline & Total & 100 \\
\hline \multirow{7}{*}{$\begin{array}{l}\text { Sumber } \\
\text { pengaruh }\end{array}$} & Orang tua & 31 \\
\hline & Suami/istri & 13 \\
\hline & Keluarga & 18 \\
\hline & Teman/lingkungan & 6 \\
\hline & $\begin{array}{l}\text { Penjual jamu } \\
\text { gendong }\end{array}$ & 11 \\
\hline & Sendiri & 21 \\
\hline & Total & 100 \\
\hline \multirow{5}{*}{$\begin{array}{l}\text { Waktu } \\
\text { konsumsi }\end{array}$} & Pagi hari & 77 \\
\hline & Siang hari & 13 \\
\hline & Sore hari & 7 \\
\hline & Pagi dan sore hari & 3 \\
\hline & Total & 100 \\
\hline \multirow{5}{*}{$\begin{array}{l}\text { Frekuensi } \\
\text { (kali/minggu) }\end{array}$} & $<2$ & 21 \\
\hline & $2-4$ & 43 \\
\hline & $5-7$ & 35 \\
\hline & $>7$ & 1 \\
\hline & Total & 100 \\
\hline \multirow{6}{*}{$\begin{array}{l}\text { Tingkat } \\
\text { pengeluaran } \\
\text { (Rp/minggu) } \\
\text { untuk konsumsi } \\
\text { jamu gendong }\end{array}$} & $<1.000$ & 12 \\
\hline & $1.001-3.000$ & 28 \\
\hline & $3.001-5.000$ & 30 \\
\hline & $5.001-7.000$ & 25 \\
\hline & $>7.000$ & 5 \\
\hline & Total & 100 \\
\hline
\end{tabular}

Tingkat Kepuasan Konsumen Jamu Gendong

Konsumen akan melakukan proses evaluasi pascapembelian terhadap konsumsi yang telah dilakukan. Hasil evaluasi bisa berupa puas atau tidak puas terhadap produk dan jasa. Menurut Mowen dan Minor (2002), kepuasan didefinisikan sebagai keseluruhan sikap yang ditunjukkan konsumen atas barang/jasa setelah memperoleh dan menggunakannya.

Pada Tabel 4 terlihat bahwa pada umumnya konsumen sudah merasa puas terhadap berbagai atribut jamu gendong, baik atribut produk maupun pelayanan. Hal ini terlihat pada persentase terbanyak 
pada setiap atribut terdapat tingkat kepuasan konsumen pada kategori puas.

Pada umumnya konsumen dalam melakukan pembelian suatu produk atau jasa berharap bahwa barang atau jasa tersebut dapat memberikan manfaat/khasiat. Sebagian besar konsumen $(72 \%)$ merasa puas terhadap khasiat yang terdapat dalam jamu gendong dan hanya $1 \%$ yang merasa tidak puas dan tidak ada yang merasa sangat tidak puas.

Tabel 4. Sebaran tingkat kepuasan konsumen jamu gendong contoh

\begin{tabular}{|c|c|c|c|c|c|}
\hline \multirow{2}{*}{ Atribut } & \multicolumn{5}{|c|}{ Tingkat Kepuasan (\%) } \\
\hline & STP & TP & B & $\mathbf{P}$ & SP \\
\hline Khasiat & 0 & 1 & 20 & 72 & 7 \\
\hline Warna & 1 & 11 & 13 & 69 & 6 \\
\hline Aroma & 0 & 0 & 8 & 84 & 8 \\
\hline Rasa & 0 & 1 & 11 & 82 & 6 \\
\hline Variasi & 0 & 2 & 16 & 78 & 4 \\
\hline $\begin{array}{l}\text { Kemudahan } \\
\text { memperoleh }\end{array}$ & 0 & 0 & 6 & 88 & 6 \\
\hline Harga & 0 & 1 & 6 & 83 & 10 \\
\hline Kebersihan gelas & 2 & 8 & 15 & 63 & 12 \\
\hline Kebersihan bakul & 0 & 2 & 17 & 71 & 10 \\
\hline Kebersihan botol & 0 & 4 & 12 & 72 & 12 \\
\hline Kebersihan lap & 0 & 4 & 18 & 66 & 12 \\
\hline Kebersihan air & 1 & 11 & 11 & 68 & 9 \\
\hline $\begin{array}{l}\text { Kandungan jamu } \\
\text { gendong }\end{array}$ & 0 & 0 & 5 & 78 & 17 \\
\hline $\begin{array}{l}\text { Keterampilan } \\
\text { penjual jamu } \\
\text { gendong }\end{array}$ & 0 & 0 & 12 & 85 & 3 \\
\hline $\begin{array}{l}\text { Kecepatan } \\
\text { melayani }\end{array}$ & 0 & 0 & 16 & 82 & 2 \\
\hline $\begin{array}{l}\text { Kecepatan } \\
\text { menanggapi } \\
\text { keluhan }\end{array}$ & 0 & 1 & 20 & 75 & 4 \\
\hline $\begin{array}{l}\text { Ketepatan } \\
\text { pesanan }\end{array}$ & 0 & 1 & 13 & 84 & 2 \\
\hline $\begin{array}{l}\text { Keramahan } \\
\text { penjual jamu } \\
\text { gendong }\end{array}$ & 0 & 0 & 5 & 86 & 9 \\
\hline $\begin{array}{l}\text { Penampilan } \\
\text { penjual jamu } \\
\text { gendong }\end{array}$ & 0 & 1 & 31 & 66 & 2 \\
\hline $\begin{array}{l}\text { Kemampuan } \\
\text { berkomunikasi }\end{array}$ & 0 & 12 & 12 & 83 & 5 \\
\hline $\begin{array}{l}\text { Kebersihan } \\
\begin{array}{l}\text { penjual jamu } \\
\text { gendong }\end{array}\end{array}$ & 0 & 1 & 14 & 75 & 10 \\
\hline Ketarangan. & 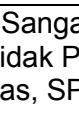 & & & & \\
\hline
\end{tabular}

Warna jamu gendong berhubungan dengan kandungan jamu gendong yang terbuat dari bahan-bahan alami seperti akar, batang, daun, dan rimpang tumbuhtumbuhan obat. Ketika diracik maka menghasilkan warna yang alami dari bahan-bahan tersebut tanpa pewarna kimia tambahan. Pada Tabel 4 terlihat bahwa lebih dari separuh konsumen $(61 \%)$ merasa puas terhadap warna jamu gendong yang mereka konsumsi.

Sebagian besar konsumen (78\%) merasa puas terhadap aroma jamu gendong dan juga terhadap rasa jamu gendong (82\%). Sebesar $78 \%$ merasa puas terhadap variasi jamu gendong, $88 \%$ konsumen merasa puas terhadap kemudahan memperoleh, $83 \%$ konsumen merasa puas terhadap harga jamu gendong, dan $72 \%$ puas terhadap kandungan jamu gendong.

Konsumen yang memperhatikan masalah kebersihan merupakan salah satu ciri responden yang peduli akan keamanan pangan dan kesehatan. Sebanyak $63 \%$ konsumen merasa puas terhadap kebersihan gelas jamu gendong, $71 \%$ merasa puas terhadap kebersihan bakul, $72 \%$ merasa puas terhadap kebersihan bakul, 66\% merasa puas terhadap kebersihan lap, dan $68 \%$ merasa puas terhadap kebersihan air.

Menurut Kotler dan Kevin (2006) kepuasan juga tergantung dari kualitas produk dan kualitas pelayanan. Sebagian besar konsumen (85\%) merasa puas terhadap keterampilan penjual jamu gendong. Sebesar 82\% konsumen merasa puas terhadap kecepatan penjual jamu gendong dalam melayani konsumen dan $75 \%$ merasa puas terhadap kecepatan penjual jamu gendong dalam menanggapi keluhan. Menurut Parasuraman, Zeithaml, dan Berry (1991) diacu dalam Rangkuti (2006) salah satu ciri-ciri kualitas jasa yang memberikan kepuasan kepada pelanggan yaitu dimensi responsiveness (cepat tanggap) yaitu kemampuan karyawan untuk membantu konsumen menyediakan jasa dengan cepat.

Berdasarkan Tabel 4 terlihat bahwa sebagian besar konsumen (84\%) merasa puas terhadap ketepatan penjual jamu dalam memenuhi pesanan konsumen dan seperti pada atribut kecepatan penjual jamu gendong dalam memenuhi pesanan, $86 \%$ merasa puas terhadap keramahan penjual jamu gendong, $83 \%$ merasa puas terhadap kemampuan komunikasi penjual jamu gendong, $75 \%$ merasa puas 
terhadap kebersihan penjual jamu gendong, dan hanya $66 \%$ yang merasa puas terhadap penampilan penjual jamu gendong.

\section{Loyalitas Konsumen}

Analisis loyalitas merupakan analisis lanjutan setelah dilakukan analisis kepuasan. Loyalitas merupakan suatu ukuran keterkaitan konsumen kepada suatu merek. Jamu gendong merupakan usaha di bidang produk sekaligus jasa. Loyalitas konsumen khususnya dalam bidang jasa terkait erat dengan elemen manusia dalam hal ini karyawan/penjual. Menurut penelitian Ferrinawati dan Djati (2004), peran karyawan (dalam penelitian ini penjual) yang handal dapat mempengaruhi loyalitas melalui rasa puas dan rasa percaya konsumen yang dihasilkan dari kinerja karyawan. Loyalitas dapat tercipta jika konsumen sudah merasa puas terhadap suatu produk.

Switcher/Price Buyer. Konsumen yang tergolong switcher (berpindahpindah) adalah konsumen yang sering berganti-ganti produk dari satu jenis/merek ke jenis/merek lainnya. Terlihat dari jawaban mereka yang menjawab "sering" atau "selalu". Hal ini menandakan bahwa konsumen sama sekali tidak loyal.

Konsumen jamu gendong yang masuk dalam kategori switcher hanya sebesar 9\%. Hal ini menunjukkan bahwa konsumen jamu gendong jarang melakukan perpindahan terhadap penjual jamu gendong lain, terlihat dari nilai ratarata sebesar 2,18 dan masuk dalam rentang skala 1,90-2,60 (kategori buruk). Dengan begitu, bisa disimpulkan bahwa konsumen dalam penelitian ini loyal terhadap jamu gendong terlihat dengan banyaknya konsumen yang tidak termasuk switcher buyer (pembeli yang sering berganti-ganti).

Hal ini juga didukung oleh Tabel 5, yang mana konsumen sebagian besar tidak jadi membeli jamu gendong apabila jenis jamu gendong yang diinginkan tidak ada. Hal ini memperlihatkan bahwa kebanyakan konsumen sering membeli jamu gendong di penjual jamu gendong langganan mereka yang sama setiap harinya dan sudah loyal pada satu jamu gendong tersebut.

Habitual Buyer. Konsumen dalam tingkatan ini adalah konsumen jamu gendong yang membeli jamu gendong didasarkan atas kebiasaan. Konsumen ini dikategorikan sebagai pembeli yang puas dan sangat puas atau setidaknya mereka tidak mengalami ketidakpuasan dari produk tersebut. Habitual buyer dihitung berdasarkan jawaban "setuju" dan "sangat setuju".

Berdasarkan hasil perhitungan, diperoleh rata-rata konsumen jamu gendong setuju bahwa keputusan membeli jamu gendong karena kebiasaan, hal ini ditunjukkan dengan nilai rata-rata yang diperoleh sebesar 3,52 dan masuk dalam rentang skala 3,50-4,20 (kategori baik). Konsumen yang masuk dalam tingkatan habitual buyer ini sebesar $65 \%$.

Tabel 5. Sebaran perilaku konsumen jika jamu gendong tidak tersedia di penjual jamu gendong langganan

\begin{tabular}{lrr}
\hline \multicolumn{1}{c}{ Perilaku konsumen } & \multicolumn{1}{c}{$\mathbf{n}$} & \multicolumn{1}{c}{$\%$} \\
\hline Pergi ke tempat lain & 5 & 5 \\
Membeli produk lain & 14 & 14 \\
Tidak jadi membeli & 79 & 79 \\
Membuat sendiri & 2 & 2 \\
\hline Total & $\mathbf{1 0 0}$ & $\mathbf{1 0 0}$ \\
\hline
\end{tabular}

Satisfied Buyer. Konsumen pada tingkatan ini adalah konsumen yang merasa puas bila melakukan pembelian suatu produk, meskipun mungkin mereka melakukan peralihan ke produk lain dengan menanggung switching cost (biaya peralihan) yang terkait dengan waktu, uang, atau risiko kinerja yang melekat dengan tindakan mereka beralih merek. Konsumen yang masuk dalam kategori satisfied adalah mereka yang menjawab "puas" dan "sangat puas" pada pertanyaan loyalitas dalam kuesioner.

Sebagian besar konsumen (83\%) dalam penelitian ini masuk ke dalam tingkatan satisfied buyer. Nilai rata-rata yang diperoleh sebesar 3,94 dan masuk pada rentang skala 3,50-4,20 yang berarti baik. Hal ini berarti konsumen merasa puas terhadap jamu gendong lain.

Likes the Brand. Konsumen dalam tingkatan likes the brand merupakan konsumen yang sungguh-sungguh menyukai jamu gendong. Konsumen yang masuk dalam tingkatan ini adalah konsumen yang menjawab "suka" dan "sangat suka" pada pertanyaan loyalitas. 
Konsumen yang masuk dalam tingkatan likes the brand yaitu sebesar $83 \%$.

Nilai rata-rata yang diperoleh sebesar 3,94 (rentang skala 3,50-4,20) yang berarti baik. Selain konsumen merasa puas terhadap jamu gendong, konsumen juga benar-benar suka mengkonsumsi jamu gendong. Rasa suka konsumen ini didasari oleh pengalaman dalam penggunaan sebelumnya, baik yang dialami pribadi maupun oleh kerabatnya maupun disebabkan oleh perceived quality yang tinggi dari jamu gendong.

Committed Buyer. Konsumen dalam tingkatan ini adalah konsumen yang setia. Pada tingkatan ini, salah satu aktualisasi loyalitas pembeli ditunjukkan oleh tindakan merekomendasikan dan mempromosikan merek tersebut kepada pihak lain. Konsumen yang termasuk dalam kategori ini adalah konsumen yang menjawab "sering" dan "selalu".

Rata-rata konsumen cukup setuju untuk mempromosikan jamu gendong kepada orang lain. Hal ini ditunjukkan oleh nilai rata-rata sebesar 2,75 yang masuk dalam rentang skala 2,70-3,40 (cukup baik). Konsumen dalam tingkatan ini sebesar $25 \%$.

Indeks Loyalitas Konsumen Jamu Gendong. Tabel 6 menunjukkan bahwa hampir separuh konsumen (45\%) mempunyai indeks loyalitas $24-47$. Indeks rata-rata yang diperoleh adalah 23,3 menunjukkan kategori loyal.

Tabel 6. Indeks loyalitas konsumen jamu gendong

\begin{tabular}{|c|c|c|}
\hline Indeks Loyalitas & $\mathbf{n}$ & $\%$ \\
\hline $16-19$ & 8 & 8 \\
\hline $20-23$ & 40 & 40 \\
\hline $24-27$ & 45 & 45 \\
\hline $28-31$ & 7 & 7 \\
\hline Total & \multicolumn{2}{|c|}{100} \\
\hline Rata-rata $\pm S D$ & \multicolumn{2}{|c|}{$23,3 \pm 2,9$} \\
\hline
\end{tabular}

Hubungan antara Tingkat Kepuasan dengan Karakteristik Konsumen

Sebagian besar konsumen $(81,4 \%)$ yang merasakan puas terhadap jamu gendong yaitu konsumen pada usia 21-40 tahun. Hasil uji statistik dengan chisquare menyatakan bahwa tidak ada hubungan yang signifikan antara usia dengan tingkat kepuasan terhadap jamu gendong.
Sebagian besar konsumen (80\%) yang merupakan suku Sunda maupun luar Sunda merasa puas terhadap jamu gendong. Hasil uji statistik memperlihatkan bahwa tidak ada hubungan yang signifikan antara suku bangsa dengan tingkat kepuasan. Sedangkan status pernikahan mempunyai hubungan yang signifikan dengan tingkat kepuasan terhadap jamu gendong $(p>0,05)$. Pada Tabel 7 terlihat bahwa persentase terbesar $(85,9 \%)$ yang merasa puas terhadap jamu gendong adalah konsumen dengan kategori sudah menikah.

Menurut Pali (1994) jamu merupakan ramuan yang muncul sebagai akibat adanya masalah yang dihadapi masyarakat pada jaman dulu, yaitu bagaimana merawat tubuh dan mengobati berbagai macam penyakit. Konsumen yang sudah menikah cenderung mempunyai masalah kesehatan khususnya wanita, seperti adanya masalah keputihan, ingin awet muda, mempertahankan kondisi tubuh pada saat hamil, untuk menjaga janin yang ada dalam kandungan, untuk menjaga kemesraan pasangan suami istri, dan lain-lain. Hal ini terkait dengan

Tabel 7. Tabulasi silang tingkat kepuasan konsumen berdasarkan karakteristik konsumen

\begin{tabular}{|c|c|c|c|c|c|}
\hline \multirow{3}{*}{\multicolumn{2}{|c|}{$\begin{array}{c}\text { Karakteristik } \\
\text { Konsumen }\end{array}$}} & \multicolumn{4}{|c|}{ Tingkat Kepuasan } \\
\hline & & \multicolumn{2}{|c|}{ Biasa } & \multicolumn{2}{|c|}{ Puas } \\
\hline & & $\mathbf{n}$ & $\%$ & $\mathbf{n}$ & $\%$ \\
\hline \multirow[t]{5}{*}{ Usia (tahun) } & $12-20$ & 3 & 37,5 & 5 & 62,5 \\
\hline & $21-40$ & 11 & 18,6 & 48 & 81,4 \\
\hline & $41-65$ & 6 & 18,8 & 26 & 81,2 \\
\hline & $>65$ & 0 & 0 & 1 & 100 \\
\hline & $p$ value & \multicolumn{4}{|c|}{0,720} \\
\hline \multirow[t]{3}{*}{ Suku bangsa } & Sunda & 19 & 20,0 & 76 & 80,0 \\
\hline & $\begin{array}{l}\text { Luar } \\
\text { Sunda }\end{array}$ & 1 & 20,0 & 4 & 80,0 \\
\hline & $p$ value & \multicolumn{4}{|c|}{0,869} \\
\hline \multirow[t]{3}{*}{$\begin{array}{l}\text { Status } \\
\text { pernikahan }\end{array}$} & $\begin{array}{l}\text { Belum } \\
\text { menikah }\end{array}$ & 8 & 53,3 & 7 & 46,7 \\
\hline & Menikah & 12 & 14,1 & 73 & 85,9 \\
\hline & $p$ value & \multicolumn{4}{|c|}{0,002} \\
\hline \multirow[t]{5}{*}{ Pendidikan } & SD & 1 & 4,0 & 24 & 96,0 \\
\hline & SMP & 4 & 21,1 & 15 & 78,9 \\
\hline & SMA & 9 & 21,4 & 33 & 78,6 \\
\hline & $\begin{array}{l}\text { PT } \\
\text { (D3/S1) }\end{array}$ & 6 & 42,9 & 8 & 57,1 \\
\hline & $p$ value & \multicolumn{4}{|c|}{0,049} \\
\hline \multirow[t]{3}{*}{ Pekerjaan } & $\begin{array}{l}\text { Tidak } \\
\text { bekerja }\end{array}$ & 15 & 19,0 & 64 & 81,0 \\
\hline & Bekerja & 5 & 23,8 & 16 & 76,2 \\
\hline & $p$ value & \multicolumn{4}{|c|}{0,755} \\
\hline \multirow{3}{*}{$\begin{array}{l}\text { Pendapatan } \\
\text { keluarga } \\
\text { (Rp/bulan) }\end{array}$} & $\leq 1,5$ juta & 13 & 15,3 & 72 & 84,7 \\
\hline & $>1,5$ juta & 7 & 46,7 & 8 & 53,3 \\
\hline & $p$ value & \multicolumn{4}{|c|}{0,016} \\
\hline
\end{tabular}


berbagai khasiat jamu gendong yang dapat memenuhi masalah-masalah tersebut, sehingga konsumen yang sudah menikah cenderung puas terhadap jamu gendong.

Selain itu, sebagian besar konsumen (96\%) yang merasa puas terhadap jamu gendong mempunyai pendidikan terakhir SD. Hasil uji statistik menyatakan bahwa ada hubungan yang signifikan $(p<0,05)$ antara pendidikan dengan tingkat kepuasan terhadap jamu gendong. Sumarwan (2004) menyatakan bahwa tingkat pendidikan seseorang dapat mempengaruhi pemilihan terhadap suatu produk dan penilaian terhadap produk tersebut. Tidak ada hubungan yang signifikan antara pekerjaan dengan tingkat kepuasan terhadap jamu gendong. Sedangkan pendapatan keluarga mempunyai hubungan yang signifikan dengan tingkat kepuasan $(p<0,05)$. Hal ini diduga karena konsumen yang mempunyai pendapatan tinggi cenderung lebih memilih obat tradisional yang mempunyai prestise yang lebih tinggi. Menurut Rangkuti (2006), salah satu faktor yang menentukan kepuasan pelanggan adalah faktor yang bersifat pribadi.

\section{Atribut-atribut yang Mendasari Tingkat Kepuasan Konsumen}

Analisis faktor digunakan untuk mengelompokkan beberapa variabel yang memiliki kemiripan untuk dijadikan satu faktor sehingga diperoleh enam faktor. Dalam penelitian ini dilakukan analisis faktor untuk menganalisis atribut-atribut apa saja yang mempengaruhi kepuasan konsumen jamu gendong.

Faktor Pertama: Kebersihan. Pada Tabel 8 terlihat bahwa, faktor pertama disusun oleh lima variabel penciri yaitu kebersihan botol-botol, kebersihan lap, kebersihan air, kebersihan gelas, kebersihan bakul, dan kebersihan penjual jamu gendong. Faktor pertama ini mempunyai nilai eigen value terbesar $(7,061)$ dibandingkan dengan nilai eigen value faktor lainnya, sehingga dapat disimpulkan bahwa faktor ini merupakan faktor dominan.

Kebersihan/hygiene dan kandungan jamu gendong merupakan salah satu faktor yang mempengaruhi kepuasan konsumen jamu gendong. Kebersihan sangat penting untuk semua produk makanan maupun minuman. Hal ini dikarenakan kebersihan/hygiene bisa mempengaruhi manfaat dari jamu gendong ini sendiri dan dapat mempengaruhi kesehatan konsumen. Apabila kebersihan jamu gendong tidak terjaga maka jamu gendong dapat tercemar mikroorganisme yang dapat mengganggu kesehatan konsumen.

Hubungan positif dimiliki oleh keenam variabel pada faktor pertama tersebut. Hal ini terlihat dari nilai faktor loading-nya yang menunjukkan bahwa jika kebersihan gelas, bakul, botol, lap, air, dan penjual jamu gendong terjamin maka konsumen akan merasa puas terhadap jamu gendong.

Tabel 8. Enam faktor utama yang mendasari tingkat kepuasan konsumen

\begin{tabular}{|c|c|c|c|}
\hline Faktor & $\begin{array}{l}\text { Eigen } \\
\text { Value }\end{array}$ & Variabel & $\begin{array}{c}\text { Factor } \\
\text { Loading }\end{array}$ \\
\hline Faktor 1 & \multirow[t]{6}{*}{7,061} & (X10) & 0,873 \\
\hline \multirow[t]{5}{*}{ Kebersihan } & & (X11) & 0,863 \\
\hline & & (X12) & 0,846 \\
\hline & & $(\mathrm{X} 8)$ & 0,794 \\
\hline & & (X9) & 0,708 \\
\hline & & (X21) & 0,660 \\
\hline \multirow{5}{*}{$\begin{array}{l}\text { Faktor } 2 \\
\text { Karakteristik } \\
\text { produk jamu } \\
\text { gendong } \\
\text { Faktor } 3\end{array}$} & \multirow[t]{4}{*}{2,150} & (X4) & 0,744 \\
\hline & & (X1) & 0,732 \\
\hline & & (X5) & 0,650 \\
\hline & & (X13) & 0,619 \\
\hline & \multirow[t]{3}{*}{1,714} & (X20) & 0,758 \\
\hline \multirow{2}{*}{$\begin{array}{l}\text { Karakteristik } \\
\text { penjual jamu } \\
\text { gendong }\end{array}$} & & (X19) & 0,732 \\
\hline & & (X14) & 0,637 \\
\hline Faktor 4 & \multirow[t]{2}{*}{1,362} & $(X 2)$ & 0,714 \\
\hline $\begin{array}{l}\text { Warna jamu } \\
\text { gendong dan } \\
\text { pelayanan } \\
\text { penjual jamu } \\
\text { gendong }\end{array}$ & & 5) & 845 \\
\hline Faktor 5 & \multirow[t]{4}{*}{1,121} & (X18) & 0,888 \\
\hline Keramahan & & (X17) & 0,519 \\
\hline $\begin{array}{l}\text { dan daya } \\
\text { tanqqap }\end{array}$ & & (X16) & 0,471 \\
\hline \multirow{3}{*}{$\begin{array}{l}\text { tanggap } \\
\text { penjual jamu } \\
\text { gendong } \\
\text { Faktor } 6 \\
\text { Bauran } \\
\text { pemasaran }\end{array}$} & & & \\
\hline & \multirow{2}{*}{1,045} & $(X 7)$ & 0,746 \\
\hline & & (X6) & 0,667 \\
\hline
\end{tabular}

Faktor Kedua: Karakteristik Produk Jamu Gendong. Faktor kedua yang mendasari tingkat kepuasan konsumen jamu gendong adalah karakteristik dari produk jamu gendong itu sendiri. Menurut Kotler (2006) kepuasan konsumen tergantung dari kualitas 
produk. Kualitas ini adalah total dari fitur dan karakteristik dari suatu produk atau jasa yang dapat memenuhi kemampuan untuk tingkat kepuasan dan kebutuhan.

Variabel yang termasuk dalam faktor ini adalah rasa jamu gendong, khasiat jamu gendong, variasi/macam jamu gendong, dan kandungan jamu gendong. Berdasarkan nilai loading pada Tabel 8 terdapat korelasi yang positif dari keempat variabel tersebut. Hal itu menunjukkan bahwa jika rasa jamu gendong enak, khasiatnya terasa, terdapat keragaman jenis, dan terbuat dari kandungan bahan-bahan alami, maka akan mendorong terjadinya kepuasan konsumen.

Faktor Ketiga: Karakteristik Penjual Jamu Gendong. Faktor ketiga dinamakan karakteristik penjual jamu gendong karena terdiri dari variabelvariabel yang merupakan unsur dari karakteristik penjual jamu gendong, penampilan penjual jamu gendong, dan kemampuan berkomunikasi penjual jamu gendong. Selain faktor produk jamu gendong, faktor dari penjual jamu gendong pun mempengaruhi kepuasan konsumen akan jamu gendong. Menurut Kotler (2006) kepuasan juga tergantung dari kualitas produk dan kualitas pelayanan,

Faktor Keempat: Warna Jamu Gendong dan Pelayanan Penjual Jamu Gendong. Faktor keempat ini terdiri dari variabel-variabel seperti variabel warna jamu gendong dan kecepatan penjual jamu gendong dalam melayani konsumen. Berdasarkan nilai loading pada Tabel 8, terdapat korelasi yang positif dari kedua variabel ini, maka dapat disimpulkan bahwa jika warna jamu gendong tidak terlalu kusam dan terdapat kecepatan dalam melayani konsumen maka akan mempengaruhi terjadinya kepuasan konsumen.

Faktor Kelima: Daya Tanggap dan Keramahan Penjual Jamu Gendong. Faktor kelima ini dinamakan faktor keramahan dan daya tanggap penjual jamu gendong dikarenakan faktor ini terdiri dari variabel keramahan dan kesopanan penjual jamu gendong serta ketepatan memenuhi pesanan.

Hubungan positif dari kedua variabel tersebut dapat disimpulkan bahwa jika penjual jamu ramah dan sopan dalam melayani serta tepat dalam memenuhi pesanan maka akan mendasari terjadinya kepuasan konsumen.

Faktor Keenam: Bauran

Pemasaran. Faktor keenam adalah faktor harga dan kemudahan dalam memperoleh jamu gendong. Variabel yang termasuk dalam faktor ini adalah harga jamu gendong dan kemudahan dalam memperoleh jamu gendong. Berdasarkan nilai loading pada kedua variabel ini, terdapat hubungan positif antara kedua variabel tersebut, hal ini berarti jika jamu gendong mempunyai harga yang terjangkau dan mudah diperoleh maka akan mendorong terjadinya kepuasan konsumen.

\section{Strategi Pemasaran Jamu Gendong}

Mc Carthy dalam Kotler (2006) menyebutkan bahwa ada empat jenis bauran pemasaran yaitu strategi produk, harga, promosi, dan tempat/distribusi. Adapun strategi yang disarankan dalam penelitian ini adalah:

1. Strategi produk, dengan menjaga kebersihan produk; mencantumkan label nama jenis jamu gendong pada setiap botolnya; menghadirkan varian rasa seperti campuran ekstrak buah-buahan asli atau tambahan rasa lain untuk mengurangi rasa pahit ini; memperhatikan kualitas dari produk jamu gendong buatan tanpa menggunakan bahan kimia tambahan.

2. Strategi harga, dengan mempertahankan harga dari jamu gendong ini dengan tidak mengubah kualitas dari jamu gendong. Strategi promosi dilakukan cukup dari mulut ke mulut (word of mouth) dan melakukan interaksi langsung dengan konsumen untuk mempromosikan jamu gendong yang merupakan obat atau minuman tradisional yang mempunyai banyak manfaat, bukan hanya untuk pengobatan tetapi untuk memelihara kesehatan.

3. Strategi distribusi, dengan melakukan pemetaan terhadap lokasi berjualan mereka secara teratur agar tidak terjadi kekosongan produk jamu gendong di suatu wilayah tertentu, rutin menjajakan jamunya setiap hari dan kalaupun sempat dijual pada dua waktu yaitu pagi dan sore hari, menggunakan 
kendaraan seperti motor ataupun sepeda sehingga dapat menghemat waktu dan dapat menjangkau lebih banyak konsumen. Namun, harus dipertimbangkan kembali antara pendapatan yang diterima dengan biaya yang dikeluarkan.

\section{KESIMPULAN DAN SARAN}

\section{Kesimpulan}

Pada umumnya konsumen sudah merasa puas terhadap atribut produk jamu gendong seperti khasiat, warna, aroma, rasa, keragaman, kemudahan memperoleh, harga, kebersihan (gelas, bakul, botol, lap, dan air), dan kandungan jamu gendong. Persentase terkecil tingkat kepuasan konsumen yaitu pada kebersihan gelas. Selain itu sebagian besar konsumen juga merasa puas terhadap berbagai atribut pelayanan jamu gendong dan persentase terkecil tingkat kepuasan konsumen yaitu pada penampilan penjual jamu gendong.

Sebagian besar konsumen sudah loyal terhadap jamu gendong namun tidak sampai pada tahap mempromosikan kepada orang lain. Hampir separuh konsumen mempunyai indeks loyalitas 24-47 dengan indeks rata-rata 23,3 (kategori loyal).

Faktor-faktor yang mempunyai hubungan nyata dengan tingkat kepuasan konsumen jamu gendong adalah status pernikahan, tingkat pendidikan, dan tingkat pendapatan keluarga per bulan. Hal ini terlihat dari uji statistik dengan menggunakan chi square $(p<0,05)$.

Atribut-atribut yang mendasari tingkat kepuasan konsumen terdiri dari enam faktor utama yaitu faktor kebersihan, karakteristik produk, karakteristik penjual jamu gendong, warna dan pelayanan penjual jamu gendong, keramahan dan daya tanggap penjual jamu gendong, dan bauran pemasaran.

Analisis strategi pemasaran yang disarankan terdiri dari empat bauran pemasaran yaitu strategi produk, harga, promosi, dan distribusi. Strategi produk diantaranya menjaga kebersihan jamu gendong baik produk juga penjual, mencantumkan label nama jenis jamu gendong pada setiap botolnya menghadirkan varian rasa seperti campuran ekstrak buah-buahan asli untuk mengurangi rasa pahit ini, dan memperhatikan kualitas dari produk jamu gendong buatan tanpa menggunakan bahan kimia tambahan. Strategi harga dengan mempertahankan harga yang terjangkau. Strategi promosi yaitu mengandalkan promosi word of mouth. Strategi distribusi dengan pemetaan lokasi yang teratur dan distribusi dengan menggunakan motor atau sepeda.

\section{Saran}

Berdasarkan hasil penelitian yang diperoleh, maka saran penelitian yang dapat dipertimbangkan yaitu sebaiknya penjual jamu gendong mempertahankan kesegaran dan kebersihan jamu gendong, mencantumkan label nama jenis jamu pada setiap botol, serta melakukan pemetaan lokasi agar tidak terjadi kekosongan jamu gendong di wilayah tertentu.

\section{DAFTAR PUSTAKA}

Durianto D, Sugiarto, Sitinjak T. 2004. Strategi Menaklukkan Pasar Melalui Riset Ekuitas dan Perilaku Merek. Jakarta: PT Gramedia Pustaka Utama.

Dwiyono S. 2007. [ppiindia] Jumlah Penduduk Dunia Terus Bertambah. http://www.mail-archive.com [30 Maret 2007].

Ferrinawati E, Pantja DS. 2004. Upaya Mencapai Loyalitas Konsumen dalam Perspektif Sumber Daya Manusia. Jurnal Manajemen \& Kewirausahaan 6: 15-26 [1 Maret 2006].

Kotler P, Kevin K. 2006. Marketing and Management. New Jersey: Pearson Education, Inc

[MTIC] Martha Tilaar Innovation Center. 2002. Budidaya secara Organik: Tanaman Obat Rimpang. Jakarta: Penebar Swadaya.

Mowen JC, Minor M. 2001. Perilaku Konsumen. Kartini Y, penerjemah; Nurcahyo M, editor. USA: Harcout College Publisher. Terjemahan dari: Customer Behaviour, $5^{\text {th }}$ Ed.

Pali E. 1994. Penjual Jamu Gendong: Motivasi Kaum Wanita Memasuki Profesi Penjual Jamu Gendong dan Peranannya dalam Keluarga (Kasus di Kota Salatiga) [tesis]. Bogor: 
Program Pascasarjana, Institut Pertanian Bogor.

Rangkuti F. 2002. Measuring Customer Satisfaction. Jakarta: Grasindo.

Sumarwan U. 2004. Perilaku Konsumen: Teori dan Penerapannya dalam Pemasaran. Bogor: Ghalia Indonesia.

\footnotetext{
*Korespondensi :

Departemen IImu Keluarga dan Konsumen Fakutas Ekologi Manusia IPB

JI. Lingkar Kampus IPB Dramaga 16680

Telp : +62-251 8628303

Email : md_djamaludin@yahoo.co.id
} 